Website: http://bcsdjournals.com/index.php/mejrhss ISSN 2709-0140 (Print) and ISSN 2709-152X (Online)

\title{
The Employment of Motivation Strategies by ESL Teachers in Language Teaching in the Philippines
}

\author{
Roma Marian Guadaña ${ }^{1}$ \\ ${ }^{1}$ Department of Education, Pag-asa National High School, Philippines
}

\begin{tabular}{|c|c|}
\hline Articl & Abstract \\
\hline$\overline{A r t i}$ & ootivation strategies employed by \\
\hline d: $27 \mathrm{Al}$ & high school English Language teachers in conducting their lessons in English \\
\hline Revi & language teaching. It also aims to examine the relationship between the \\
\hline Acc & $\begin{array}{l}\text { motivation strategies employed by English Language Teachers and the parts } \\
\text { of the lesson in which the strategies are used. }\end{array}$ \\
\hline Keywords: & Approach/Methodology/Design: Descriptive Correlational Design was \\
\hline $\begin{array}{l}\text { Motivational Strategies, } \\
\text { Lesson, }\end{array}$ & $\begin{array}{l}\text { employed in this study. Purposive sampling was utilized in the study which } \\
\text { comprised of eight English teachers of Pag-asa National High School, }\end{array}$ \\
\hline Language Teaching, & Philippines. Mean $(X)$ and Pearson-r were used for the interpretation of data. \\
\hline $\begin{array}{l}\text { ESL, } \\
\text { Education }\end{array}$ & $\begin{array}{l}\text { Findings: The results of the study showed that out of forty eight listed } \\
\text { motivation strategies only eighteen motivational strategies are performed by }\end{array}$ \\
\hline & $\begin{array}{l}\text { the English teachers. Also, motivation strategies directed to promoting } \\
\text { learners' confidence are mostly utilized by the teachers and the different parts }\end{array}$ \\
\hline Pap & of the lesson are associated with the motivational strategies. The study is \\
\hline Res & $\begin{array}{l}\text { limited only to identifying the motivational strategies used by the teachers and } \\
\text { how these motivational strategies are related to teaching English in Pag-asa }\end{array}$ \\
\hline Corresponding Author: & $\begin{array}{l}\text { National High School. } \\
\text { Practical Implications: This study may aid the teachers in understanding }\end{array}$ \\
\hline & mploy enough motivational strategies in their classes. \\
\hline $\begin{array}{l}\text { Email: } \\
\text { romamarian.guadana@deped.gov.ph }\end{array}$ & $\begin{array}{l}\text { Originality/value: The results of this study may be used as a basis in } \\
\text { conducting Learning Action Cell (LAC) Sessions among English teachers in } \\
\text { terms of managing English classes and using of motivation strategies. }\end{array}$ \\
\hline
\end{tabular}

\section{Introduction}

Over the past years, motivation has been the focus of a number of studies in language education. Motivation may be described in various ways depending on the context. Dornyei (2001) pointed out that "motivation explains why people decide to do something, how hard they are going to pursue it and how long they are willing to sustain the activity" (p.7). On the other hand, Gardner (1985) opted to explain motivation by using the question, "Why does an organism behave as it does?" and that motivation involves four aspects which are goal, effortful behaviour, desire to attain the goal, and favourable attitudes toward the activity (p.50).

Learning occurs not just inside the classroom. It happens when a person starts to give realization and interpretation to an idea that is unfamiliar to them. Ornstein (1990) defines 
learning as a reflective process whereby the learner either develops new insights and understanding on changes or restructures his or her mental processes. Desire to learn is one of the signs that a person is curious to explore the answers to every unfamiliar experience to achieve maturation.

According to Lardizabal (1991), learning is an integrated, ongoing process occurring within the individual enabling him to meet specific aims, fulfil his needs and interest, and cope with the learning process. People are all capable of learning things, but the challenge that teachers face is on how to make learners possess the inner drive to satisfy their curiosity. Franken (1994) states that motivation is the arousal, direction, and persistence of behaviour. All these ideas about motivational strategies put much pressure on teachers to adopt and adapt certain motivational strategies that correspond to their contexts and students' needs. Hence, this study is an attempt to examine the motivational strategies employed by the teachers at Pag-asa National High School in the Philippines.

\section{Literature Review}

One thing to note in motivation particularly on second language motivation is that according to Dornyei (1994) "we can foresee in future L2 motivation research a dynamic interplay of established motivational concepts grounded in a social psychological approach and constructs rooted in other psychological fields and approaches" (p.522). In addition, Dornyei (1998) emphasized the importance of motivation as a factor in the success of learning of the students and the skills of the teachers. In terms of employing motivation, it should also be considered in relation to the effectiveness of teaching.

These studies had been a powerful means to understand and analyze teaching and learning process in relation to second/foreign language or language acquisition. For example, motivation in the language classroom may have a difference depending on the disposition of either male or female students. Dornyei and Clement (2001) found out that boys and girls have differences in their dispositions toward different languages having the girls to get high scores on motivation and attitude measures. While some students are having difficulty in learning English as a language, Kitjaroonchai (2013) has found out that the motivation of the students to learn English is considerably high in relation to the idea that learning English will help the students in their future. In addition to this, students who excelled academically have a slightly higher motivation than the other students.

The previous studies looked into the effect of motivation to student; however it is also important to look on the side of the teachers when it comes to motivation particularly on the motivation strategies they have been employing in the classroom. Dornyei (2001) emphasized motivation strategies as "techniques that promote the individual's goal-related behaviour [...] Motivational strategies refer to those motivational influences that are consciously exerted to achieve some systematic and enduring positive effect" (p.28).

Dornyei (2001) underscored the motivational strategies including those that were proven to be reliable should not be considered as golden rules to be followed but rather suggestions that may 
help the teachers and may work better on a certain day but not necessarily the next day. This only shows that the array of motivation strategies should be seen as a guide to what strategy is best for a certain activity. Appropriateness of the strategy to be employed is still the primary factor to be considered. In addition to this, a study conducted by Schmidt and Watanabe (2001) on the motivation, strategy use, and pedagogical references in foreign language learning have strengthened the notion that motivation affects learning. Their study had shown that aspects of motivation do not equally affect strategy use and that not all strategies are affected equally by factors concerning motivation. This may show that motivation strategies may be something that transcends but may be limited to certain context or culture.

Motivation strategies in ELT are factors in encouraging the learners to engage themselves in the learning process. It also makes language learning more enjoyable through the arousal of the learners' interest. According to Cheng and Dornyei (2007), the motivation of the learners is a key variable in making language learning effective which is anchored from the definition of motivation, teaching perception, and learning the study about the motivation strategies employed by high school teachers in ELT.

A study conducted by Cheng and Dornyei (2007) on the use of motivation strategies in EFL (English as Foreign Language) teaching in Taiwan has provided that some motivation strategies may transfer across cultures and ethno linguistic contexts. Thus motivation strategies used in a certain class may be similar to other classes or contexts. Skinner and Belmont (1993) also emphasized in their study that the behaviour of the teacher and the engagement of the students in the classroom have a reciprocal relationship. This shows that motivation of the students is related to the teachers' actions in class underscoring that motivation being employed by the teachers may have a direct effect to the students.

Lastly, Kassing (2011) had found out in her study that some EFL lecturers were not aware of the effect of the strategies they use to the students' motivation in relation to teaching-learning English. This is very vital since success in learning English is the main goal in the teaching and learning process. Motivation strategies employed is the focal point as to the extent of how the teachers know its nature.

\section{Methodology and Procedures}

\section{Sampling}

The respondents of the study were the eight (8) High School English Language Teachers from Pag-asa National High School (PgNHS) who are in a Regular Permanent type of appointment status as approved by the Department of Education and the Civil Service Commission. The teachers are working in the above-mentioned school located at Victoria Reyes, City of Dasmarinas, Cavite, Philippines. Selecting the respondents was based on the use of purposive sampling intended for the limited number of teachers and the objectives designed for this paper.

\section{Data Collection}


The researcher used a descriptive research form through a descriptive correlation research. The instrument used in the study is a modified questionnaire form of the strategy scales and constituent strategies by Cheng and Dornyei (2007) based on the systematic overview of motivational techniques by Dornyei (2001).

The questionnaire was used by Cheng and Dornyei (2007) in their study of the use of motivational strategies in language instruction focusing on the English as Foreign Language (EFL) Teaching in Taiwan. The study of Cheng and Dornyei (2007) focused on (1) how important the participating teachers perceived certain motivational strategies and (2) how frequently they actually made use of these strategies in their teaching practice. Also, Dornyei and Cheng (2007) emphasized validity and reliability of the questionnaire stating that "the internal consistency of these scales was tested by means of a reliability analysis to determine whether the theoretical clustering was borne out in practice" (p.160).

The questionnaire was constructed, validated, and administrated. It consisted of 48 possible motivation strategies being employed by teachers divided into 10 clusters based on the content and similarities of such motivation strategies. Also, the modified questionnaire includes relevant information such as the length of the teacher's service and the parts of the lesson where the teacher employs such motivation strategies.

The researcher made sure that each respondent's answers are confidential and anonymous by highlighting the cover letter and the instructions in the survey questionnaire. In addition, the researcher sent a letter of request to conduct a study to the principal and the head of the English Department of Pag-asa National High School. By the time the principal and the head agreed to permit the researcher, the questionnaires were distributed to the respondents.

A day was given to the respondents to answer the questionnaire. Afterwards, the questionnaires were then collected for data analysis and interpretation. The data gathered were encoded and computed using Microsoft Excel 2010 through SPSS software. The data were analyzed and interpreted from which the results and discussion were drawn.

\section{Results and Discussion}

\section{Research Question 1}

Table 1: Motivation strategies utilized by English Language Teachers (ELT) of Pag-asa National High School

\begin{tabular}{lccc}
\hline \multicolumn{1}{c}{ Motivational Strategy } & Mean & SD & Statistical Range \\
Bring in and encourage humour & 3.75 & .463 & Often Performed \\
Show students you care about them & 5.75 & .463 & Always Performed \\
Allow students to get to know each other & 3.63 & .518 & Often Performed \\
$\begin{array}{l}\text { Familiarize students with the cultural background of } \\
\text { the target language }\end{array}$ & 1.00 & .000 & Never Performed \\
$\begin{array}{l}\text { Explain the importance of the class rules } \\
\text { Give clear instructions by modelling }\end{array}$ & 5.25 & .463 & $\begin{array}{l}\text { Very often Performed } \\
\end{array}$ \\
& 5.13 & .354 & $\begin{array}{l}\text { Very Often } \\
\text { Performed }\end{array}$ \\
\hline
\end{tabular}




\begin{tabular}{|c|c|c|c|}
\hline $\begin{array}{l}\text { Invite senior students to share their English learning } \\
\text { experiences }\end{array}$ & 1.00 & .000 & Never Performed \\
\hline Monitor students' progress and celebrate their victory & 3.63 & .518 & Often Performed \\
\hline Remind students of the benefits of mastering English & 3.25 & .463 & $\begin{array}{l}\text { Sometimes } \\
\text { Performed }\end{array}$ \\
\hline Encourage students to set learning goals & 5.63 & .518 & Always Performed \\
\hline Design tasks that are within students' ability & 5.50 & .535 & Always Performed \\
\hline Introduce various interesting topics & 3.75 & .463 & Often Performed \\
\hline Make tasks challenging & 3.75 & .463 & Often Performed \\
\hline Teach self-motivating strategies & 3.75 & .463 & Often Performed \\
\hline Make sure grades reflect students' effort and hard work & 6.00 & .000 & Always Performed \\
\hline Let students suggest class rules & 1.00 & .000 & Never Performed \\
\hline Show your enthusiasm for teaching & 5.63 & .518 & Always Performed \\
\hline Break the routine by varying the presentation format & 3.25 & .463 & $\begin{array}{l}\text { Sometimes } \\
\text { Performed }\end{array}$ \\
\hline Invite English-speaking foreigners to class & 1.00 & .000 & Never Performed \\
\hline $\begin{array}{l}\text { Help students develop realistic beliefs about English } \\
\text { learning }\end{array}$ & 3.00 & .000 & $\begin{array}{l}\text { Sometimes } \\
\text { Performed }\end{array}$ \\
\hline $\begin{array}{l}\text { Use a short and interesting opening activity to start } \\
\text { each class }\end{array}$ & 5.75 & .463 & Always Performed \\
\hline $\begin{array}{l}\text { Involve the students in designing and running the } \\
\text { English course }\end{array}$ & 2.00 & .535 & Rarely Performed \\
\hline Establish good rapport with the students & 5.38 & .518 & $\begin{array}{l}\text { Very Often } \\
\text { Performed }\end{array}$ \\
\hline Encourage peer teaching and group presentation & 5.25 & .463 & $\begin{array}{l}\text { Very Often } \\
\text { Performed }\end{array}$ \\
\hline $\begin{array}{l}\text { Give good reasons to students as to why a particular } \\
\text { task is meaningful }\end{array}$ & 4.25 & .463 & Often Performed \\
\hline $\begin{array}{l}\text { Find out students' needs and build them into } \\
\text { curriculum }\end{array}$ & 3.00 & .000 & $\begin{array}{l}\text { Sometimes } \\
\text { Performed }\end{array}$ \\
\hline Encourage students to create products & 5.38 & .518 & $\begin{array}{l}\text { Very Often } \\
\text { Performed }\end{array}$ \\
\hline Encourage students to try harder & 6.00 & .000 & Always Performed \\
\hline $\begin{array}{l}\text { Give students choices in deciding how and when they } \\
\text { will be assessed }\end{array}$ & 3.38 & .518 & $\begin{array}{l}\text { Sometimes } \\
\text { Performed }\end{array}$ \\
\hline $\begin{array}{l}\text { Create a supportive classroom climate that promotes } \\
\text { risk taking }\end{array}$ & 5.88 & .354 & Always Performed \\
\hline $\begin{array}{l}\text { Display the class goal in a wall chart and review it } \\
\text { regularly }\end{array}$ & 3.38 & .518 & $\begin{array}{l}\text { Sometimes } \\
\text { Performed }\end{array}$ \\
\hline Introduce authentic cultural materials & 4.00 & .000 & Often Performed \\
\hline $\begin{array}{l}\text { Make clear to students that communicating meaning } \\
\text { effectively is more important than being grammatically } \\
\text { correct }\end{array}$ & 6.00 & .000 & Always Performed \\
\hline Provide students with positive feedback & 6.00 & .000 & Always Performed \\
\hline Ask students to work toward the same goal & 6.00 & .000 & Always Performed \\
\hline Teach students learning techniques & 3.50 & .535 & Often Performed \\
\hline Adopt the role of a facilitator & 4.50 & .535 & $\begin{array}{l}\text { Very Often } \\
\text { Performed }\end{array}$ \\
\hline $\begin{array}{l}\text { Encourage students to use English outside the } \\
\text { classroom }\end{array}$ & 3.63 & .518 & Often Performed \\
\hline Increase the amount of English in your class & 5.88 & .354 & Always Performed \\
\hline $\begin{array}{l}\text { Share with the students that you value English as a } \\
\text { meaningful experience }\end{array}$ & 5.88 & .354 & Always Performed \\
\hline
\end{tabular}




\begin{tabular}{|c|c|c|c|}
\hline Avoid social comparison & 5.50 & .535 & Always Performed \\
\hline Promote effort attributions & 5.63 & .518 & Always Performed \\
\hline $\begin{array}{l}\text { Make tasks attractive by including novel and fantasy } \\
\text { element }\end{array}$ & 5.88 & .354 & Always Performed \\
\hline $\begin{array}{l}\text { Encourage students to share personal experiences and } \\
\text { thoughts }\end{array}$ & 3.88 & .354 & Often Performed \\
\hline Present various auditory and visual teaching aids & 5.75 & .463 & Always Performed \\
\hline Recognize students' effort and achievements & 5.75 & .463 & Always Performed \\
\hline Be yourself in front of students & 4.00 & .000 & Often Performed \\
\hline Allow students to assess themselves & 4.63 & .518 & $\begin{array}{l}\text { Very Often } \\
\text { Performed }\end{array}$ \\
\hline
\end{tabular}

Source: Author

Table 1 shows that among the 48 listed motivation strategies based on the questionnaire by Cheng and Dornyei (2007), 18 motivation strategies were found to be prevalently used out of 48 motivational strategies by the English teachers of Pag-asa National High School. If variety should be considered, the 18 prevalently used motivation strategies would only comprise $37 \%$ of the listed motivational strategies. This may impact the motivation to learn the language since the ESL teachers may tend to repeat the same motivation strategies when they teach in class. As Cheng and Dornyei (2007) stated, the motivation of the learners is a key variable in making language learning effective which is anchored from the definition of motivation, teaching perception, and learning the study about the motivation strategies employed by high school teachers in ELT.

Such list of motivation strategies were identified using the following arbitrary statistical ranges:

Table 2: Arbitrary Statistical Ranges for Motivational Strategies

\begin{tabular}{ll}
\hline $5: 50-6: 00$ & Always Performed \\
$4: 50-5.49$ & Very Often Performed \\
$3.50-4: 49$ & Often Performed \\
$2.50-3.49$ & Sometimes Performed \\
$1.50-2.49$ & Rarely Performed \\
$1.00-1.49$ & Never Performed \\
\hline \multicolumn{2}{c}{ Source: Author }
\end{tabular}

Table 2 shows the arbitrary statistical ranges used to identify the motivation strategies utilized by the teachers.

\section{Research Question 2}

Table 3: Parts of the Lesson Where Motivational Strategies are Utilized

\begin{tabular}{ccc}
\hline Parts of the Lesson & Mean $(\mathbf{X})$ & SD \\
Proper teacher behaviour & 5.33 & .15 \\
Recognize students' effort & 5.25 & .30 \\
Promote learners' self-confidence & 5.40 & .19 \\
Creating a pleasant classroom & 5.22 & .34 \\
$\quad$ climate & & \\
Present tasks properly & 4.69 & .26 \\
\hline
\end{tabular}




\begin{tabular}{ccc}
\hline Increase learners' goal-orientedness & 3.75 & .23 \\
Make learning tasks stimulating & 4.63 & .33 \\
Familiarize learners with L2-related & 2.82 & .12 \\
$\quad$ values & & .09 \\
$\begin{array}{l}\text { Promote group cohesiveness and } \\
\text { group norms }\end{array}$ & 3.95 & .21 \\
$\quad$ Promote learner autonomy & 3.92 & \\
\hline
\end{tabular}

Source: Author

Table 3 shows the ten parts of the lesson wherein motivation strategies are employed. It is shown that motivation strategies directed to promoting learners' confidence with a mean of 5.40 are mostly utilized and motivation strategies directed to familiarization of learners with L2-related values with a mean of 2.82 are least utilized.

This result may imply that most of the focus of the ESL teachers is on building the confidence of the students as to fluency in using the English language, however, fluency alone may not be enough since accuracy in using the language is also needed. Moreover, the data also shows that motivation strategies directed to familiarization of learners with L2-related values with a mean of 2.82 are least utilized. This result may impact the reflection and self-management of the learners in using the second language since most of the motivation strategies employed by the ESL teachers underscored building the confidence, creating pleasant classroom climate and managing tasks. Such discussion agrees to Kassing (2011) which found out in her study that some EFL lecturers were not aware of the effect of the strategies they use to the students' motivation in relation to teaching-learning English. This is very vital since success in learning English is the main goal in the teaching and learning process. Motivation strategies employed is the focal point as to the extent of how the teachers know its nature.

\section{Research Question 3}

Table 4: Significant Relationship Between The Parts Of The Lesson And Motivational Strategies

\begin{tabular}{lllll}
\hline $\begin{array}{l}\text { Part of the } \\
\text { lesson }\end{array}$ & $\begin{array}{l}\text { Motivational } \\
\text { Strategies } \\
\text { Create a supportive } \\
\text { classroom climate that } \\
\text { promotes risk-taking }\end{array}$ & $\begin{array}{l}\text { Pearson } \\
\text { r-Value }\end{array}$ & Sig-value & Interpretation \\
$\begin{array}{l}\text { Proper } \\
\text { teacher } \\
\text { behaviour }\end{array}$ & $\begin{array}{l}\text { Increase the amount of } \\
\text { English you use in class } \\
\text { Make tasks attractive by } \\
\text { including novel and } \\
\text { fantasy element }\end{array}$ & 0.882 & 0.004 & Significant \\
$\begin{array}{l}\text { Design tasks that are } \\
\text { within students' ability }\end{array}$ & 0.866 & 0.004 & Significant \\
$\begin{array}{l}\text { Recognize } \\
\text { students' } \\
\text { effort }\end{array}$ & $\begin{array}{l}\text { Increase the amount of } \\
\text { English you use in class }\end{array}$ & & & Significant \\
& & & & \\
\hline
\end{tabular}




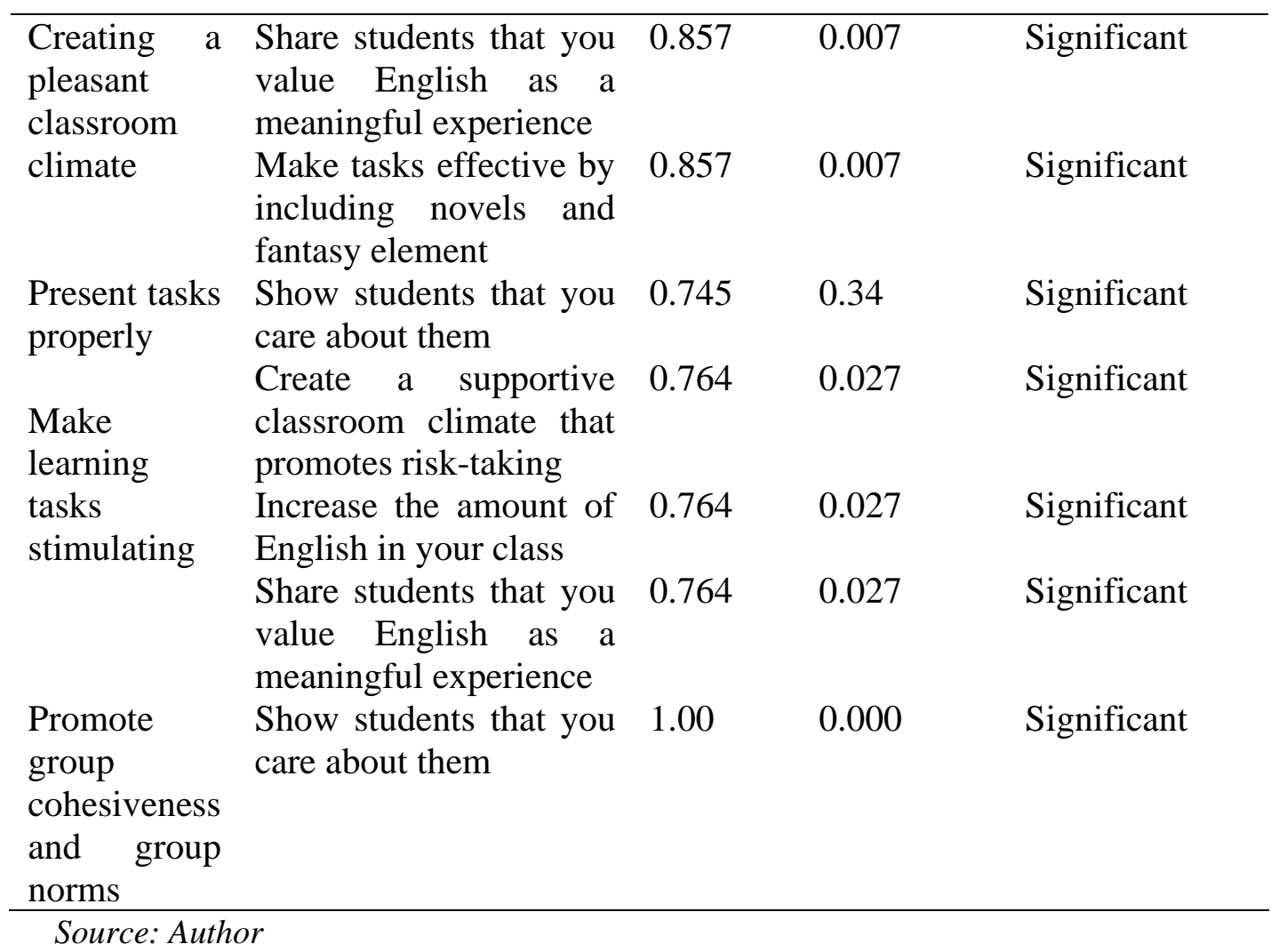

Table 4 shows the relationship of the parts of the lesson and the motivational strategies employed by the English teachers. It showed that proper teacher behaviour has a significant relationship with the following motivational strategies: creating a supportive classroom climate that promotes risk-taking, increasing the amount of English you use in class, and making tasks attractive by including novel and fantasy element. Furthermore, recognizing students' effort has a significant relationship with designing tasks that are within students' ability. Creating a pleasant classroom climate also has a significant relationship with increasing the amount of English you use in class, sharing to students that you value English as a meaningful experience, making tasks effective by including novels and fantasy element. Moreover, presenting tasks properly has a significant relationship with showing students that you care about them. Making learning tasks stimulating has significant relationship with creating a supportive classroom climate that promotes risk-taking, increasing the amount of English in your class, and sharing to students that you value English as a meaningful experience. Lastly, promoting group cohesiveness and group norms has a significant relationship with showing students that you care about them.

The results on table 4 comprehensively show a strong relationship between the various motivation strategies and the parts of the lesson in which these motivation strategies have a significant impact. This implies that ESL teachers may have been using the motivation strategies in the parts of the lesson but may not be aware that there are multiple motivation strategies on a specific part of the lesson which they can use in teaching. This would help the learners more in being successful in learning thus agrees to Kitjaroonchai (2013) which has found out that the motivation of the students to learn English is considerably high in relation 
to the idea that learning English will help the students in their future. In addition to this, students who excelled academically have a slightly higher motivation than the other students.

\section{Conclusion and Suggestion}

Based on the results of the study, it is concluded that out of 48 listed motivation strategies by Cheng and Dornyei (2007) only 18 motivational strategies are performed by the English teachers of Pag-asa National High School. This result may be due to ESL teachers' repetition of the same set of motivation strategies in their classes. ESL teachers were not fully aware of the other motivation strategies that they can apply in their lessons or classes. Thus, these results show an impact on the teaching and learning outcomes of the learners.

In addition, motivation strategies directed to promoting learners' confidence are mostly utilized by the teachers, while motivation strategies directed to familiarization of learners with L2related values are least utilized. Most of the ESL teachers' focus is on building the selfconfidence of the learners in using the language thus directed to fluency. The result may imply that due to the focus on building the confidence, the reflection and self-management of the learners in using the second language may be left behind which actually promotes critical thinking and problem-solving skills. Lastly, the different parts of the lesson are associated with the motivational strategies showing a strong relationship between the various motivation strategies and the parts of the lesson. The ESL teachers may use this relationship in classes to further enhance the motivation. This may bring about a successful learning outcome.

It is recommended that an action plan should be made by the English teachers of Pag-asa National High School in relation to the employment of motivation strategies that they use in their classes. This may aid the teachers in realizing whether they employ enough motivational strategies in their classes. Moreover, the paper would let the teachers examine their pedagogy since the employment of the motivational strategies had a significant relationship to the parts of the lesson. Lastly, the results of this study may become a basis for conducting Learning Action Cell (LAC) Sessions among the teachers.

\section{Conflict of Interest}

The author of the article declares no conflict of interest.

\section{Funding}

This research study was not funded by any institution. The author conducted the study on his own expenses.

\section{References}

Dörnyei, Z. (2001). Motivational strategies in the language classroom. Cambridge: Cambridge University Press.

Fraenkel, J. R., \&Wallen, N. E. (2009).How to design and evaluate research in education. New York, NY: McGraw-Hill. 
Franken, R. E. (1982). Human motivation. Monterey, Calif: Brooks/Cole Pub. Co.

Gardner, R. C. (1985). Social psychology and second language learning: The role of attitudes and motivation. London: E. Arnold.

Lardizabal, A. (1991). Principles and methods of teaching (3rd ed.). Quezon City, Philippines: Phoenix Publishing House.

Ornstein, A. C. (1990). Strategies for effective teaching. New York: Harper \& Row.

Cheng, H., \&Dörnyei, Z. (2007). The use of motivational strategies in language instruction: The case of EFL teaching in Taiwan. Innovation in Language Learning and Teaching, 1(1), 153-174. doi:10.2167/illt048.0

Dornyei, Z. (1994). Motivation and motivating in the foreign language classroom. The Modern Language Journal, 78(3), 273-284.

(1998). Motivation in second and foreign language learning. Language Teaching, 31(3), 117-135.

Dörnyei, Z., \& Clément, R. (2001). Motivational characteristics of learning different target languages: Results of a nationwide survey. Motivation and second language acquisition, 23, 399-432.

Kassing, J. W. (2011). Stressing out about dissent: Examining the relationship between coping strategies and dissent expression. Communication Research Reports, 28, 225234.

Kitjaroonchai, N. (2013). Motivation Toward English Language Learning of Students in Secondary and High Schools in Education Service Area Office 4, Saraburi Province, Thailand. International Journal of Language and Linguistics, 1(1), 22-33.

Schmidt, R., \& Watanabe, Y. (2001).Motivation, strategy use, and pedagogical preferences in foreign language learning. In Z. Dörnyei\& R. Schmidt (Eds.), Motivation and second language acquisition (Technical Report \#23, pp. 313-359). Honolulu: University of Hawai'i, Second Language Teaching and Curriculum Center.

Skinner, E. A., \& Belmont, M. J. (1993). Motivation in the classroom: Reciprocal effects of teacher behavior and student engagement across the school year. Journal of Educational Psychology, 85(4), 571-581. 